Crop Breeding and Applied Biotechnology 15: 210-217, 2015

Brazilian Society of Plant Breeding. Printed in Brazil

\title{
ARTICLE
}

http://dx.doi.org/10.1590/1984-70332015v15n4a37

\section{Efficiency of selection in early generations of potato families with a view toward heat tolerance}

Izabel Cristina Rodrigues de Figueiredo ${ }^{1 *}$, César Augusto Brasil Pereira Pinto ${ }^{1}$, Guilherme Henrique Martins Rodrigues Ribeiro $^{1}$, Leandro de Oliveira Lino ${ }^{2}$, Danilo Hottis Lyra ${ }^{3}$ and Carolina Mariane Moreira ${ }^{1}$

Received 20 December 2013

Accepted 03 March 2015

\begin{abstract}
The aim of this study was to evaluate the efficiency of selection of potato families in early generations for heat tolerance. Thirty families were evaluated in the seedling generation (SG), first clonal generation (FCG) in the field and greenhouse under high temperature conditions, and second clonal generation (SCG) under mild temperatures. The mean of the families was obtained in each generation. The 16 most productive families in FCG were selected, and the clones of these families were evaluated in experiments in the winter and rainy crop seasons. The results showed that family selection for tuber shape may be applied as of the SG. It was also observed that family selection in the FCG and SCG for yield and tuber specific gravity contributed to identification of clones tolerant to heat and responsive to environmental improvement.
\end{abstract}

Key words: Early selection, clones, Solanum tuberosum, thermal stress.

\section{INTRODUCTION}

Potatoes are grown in Brazil through the year in three different crop seasons: from January to March (dry crop season), from April to July (winter crop season), and from August to December (rainy crop season) (Dias 1993). These crop seasons make up around 30, 21, and 49\% of Brazilian production, respectively (IBGE 2014). Although producers seek regions less subject to the adverse effects of high temperatures in southern states and in higher altitude regions in the southeast of Brazil, ideal temperatures are generally exceeded, especially in the rainy and dry crop seasons. Temperature is the most important factor not under producers' control, which affects potato growth and production (Levy and Veilleux 2007). In general, production is optimum at mean daytime temperatures in the range of $14-22{ }^{\circ} \mathrm{C}$. Above this, yield declines drastically (Haverkort and Verhagen 2008). Hijmans (2003) estimates losses of $18-32 \%$ in worldwide potato production by the year 2050 as a result of the effects of global warming. The problem is more accentuated in tropical and subtropical regions where potato crop potential is limited by sensitivity to heat (Hancock et al. 2013). Greater than ideal temperatures bring about multiple physiological, biochemical, and molecular processes of the potato plant (Hancock et al. 2013). Thus, heat stress delays tuber development, reduces production and dry matter content of the tubers, increases respiration and the partitioning of photoassimilates to the plant shoots (Levy and Veilleux 2007), negatively affects the qualitative appearance of the tubers (Ginzberg et al. 2009), and increases the rate of physiological disorders (Benites and Pinto 2011). Thus, studies that seek to obtain heat tolerant potato clones should be a priority in Brazilian breeding programs, and efforts have been made in this direction (Benites and Pinto 2011).

Breeding programs for plants with vegetative propagation, among them potato, predominantly use clonal selection, which consists of single crosses for generation of the segregating population, as of which selection of individual clones is carried out. This procedure has been inefficient in potato breeding, especially in the initial phases of the program (Brown et al. 1987, Gopal and Minochoa 1997) when there are a small number of tubers of each clone for planting experiments with replications. In addition, the magnitude of the heritabilities among families has been greater than among individual clones (Bradshaw et al. 1998,

\footnotetext{
${ }^{1}$ Universidade Federal de Lavras (UFLA), Departamento de Biologia, CP 3037, 37.200-000, Lavras, MG, Brazil. *E-mail: izabelfigueiredo@yahoo.com.br ${ }^{2}$ INRA/GAFL 67, Allée dês Chênes CS 6009484143 Montfavet cedex Francês

${ }^{3}$ Universidade de São Paulo (USP), Escola Superior de Agricultura “Luiz de Queiroz” (ESALQ), Departamento de Genética, Av. Pádua Dias, 11, 13.418-900 Piracicaba, SP, Brazil
} 
Diniz et al. 2006), suggesting that family selection could more effectively contribute to selection gains in the initial stages of the breeding program. The greater heritability for various traits among families is due to the lesser effect of the environment among mean values of families than among individuals of the same family (Simmonds 1996, Gopal 1997, Simon et al. 2009).

In the SG and FCG generations, family selection is an alternative when selection is practiced based on traits of low individual heritability (Simmonds 1996) because, in contrast with clones, families may be evaluated in experiments with replications and in more than one location or crop season, thus improving the mean estimate of the family, as well as assisting in identification of the most stable families.

The aims of this study were to evaluate the efficiency of selection of potato families in early generations with a view toward heat tolerance and verify if the best individual clones were derived from the best families selected in the initial steps of the program.

\section{MATERIAL AND METHODS}

We evaluated 30 clonal families obtained by single crosses between clones selected through two cycles of recurrent selection for heat tolerance (Benites and Pinto 2011).

Around 100 seedlings per family were transplanted to $10 \mathrm{~cm}$ diameter $(0.5 \mathrm{~L})$ pots containing organo-mineral substrate for tuber development. In the SG, individual plants were harvested and two tubers per clone were taken. In the first clonal generation (FCG), two experiments were carried out simultaneously, one in a greenhouse and another in the experimental field of the Department of Biology, Universidade Federal de Lavras, Lavras, MG, Brazil, from October 2011 to January 2012 (rainy season - high temperatures). In the field, a randomized block design was used with three replications and plots consisting of 12 plants, for a total of 36 clones per family, with a spacing of $0.5 \mathrm{x}$ $0.8 \mathrm{~m}$. In a greenhouse, a completely randomized design was used, with three replications. Each plot consisted of 10 pots of $10 \mathrm{~cm}$ diameter $(0.5 \mathrm{~L})$ containing organo-mineral substrate. The cultivars Caesar, Asterix, and Voyager, and two heat tolerant clones, CBM 09-10 and CBM 16-16, were used as controls.

In the second clonal generation (SCG), the experiment was conducted in the experimental area of Epamig in Pouso Alegre, MG, from May to August 2012 (winter crop season) in a randomized block design with three replications. Each plot consisted of 10 plants, for a total of 30 clones per family. The controls used were the same as the FCG.
The FCG and SCG plants were harvested individually and evaluated for tuber yield; tuber specific gravity, obtained by weight in the air/(weight in the air - weight in water); periderm texture $(1=$ rough to $5=$ smooth and shiny $)$; eye depth $(1=$ deep to $5=$ shallow $)$ and shape $(1=$ round, $3=$ oval, $5=$ elongated). The scores were attributed by three evaluators.

The least square means were calculated for each family in each generation and the repeatability of the families was evaluated through correlations between the mean values of the families among all the generations. Experimental precision was verified through an accuracy estimate, as proposed by Resende and Duarte (2007). Due to the heterogeneity of residual variances in the individual analyses in the FCG (field and greenhouse) for yield, correction of the phenotypic data was carried out to proceed to combined analysis in the following manner: multiplication of the data from each environment by the ratio: mean residual standard deviation (Sme) for all the environments/residual standard deviation in environment i (Si), as described in Resende (2007). Sixteen families were selected through exhibiting higher mean values for tuber yield.

The percentages of coincidence among the families in the different generations were estimated by verifying the number of families that would be selected in one generation and in the following generation.

In evaluation of the individual clones of the families selected, two trials were conducted in the Epamig experimental area in Pouso Alegre, MG, Brazil using an average of 20 clones per family. The first experiment was conducted with second generation clones (C2) from May to August 2012 (winter crop season), using an augmented block design (ABD), with 450 clones as regular treatments, distributed in 30 blocks of 20 treatments each. The second experiment was conducted with third generation clones (C3) from December 2012 to March 2013 (rainy crop season), in an $\mathrm{ABD}$, with 400 clones as regular treatments, distributed in 20 blocks of 25 treatments each. The common treatments and the traits evaluated were the same as the family experiments. Overall appearance of the tubers $(1=$ bad to $5=$ excellent $)$ and percentage of tubers with cracking and second growth were evaluated. Plots consisted of one row of five plants spaced at $0.3 \times 0.8 \mathrm{~m}$.

Analyses were carried out using SAS software (SAS 2000), considering families and clones as random effects.

To select families (or clones) tolerant to heat and responsive to milder temperatures, graph analysis adapted from Fageria and Kluthcouski (1980) was used. On this 
graph, the mean values of the genotypes in the favorable environment ( $\mathrm{x}$ axis) and the mean values of the same genotypes under stress conditions (y axis) are plotted. Two straight lines drawn at the mean value of each environment distributes the genotypes in four quadrants: those tolerant or sensitive to heat (above or below the mean value of the $y$ axis) and those responsive or not to mild temperatures (above or below the mean value of the $\mathrm{x}$ axis). The genotypes responsive to mild temperatures and that have a higher mean value under high temperatures are in quadrant I (Figure 1) and are the desired types.

\section{RESULTS AND DISCUSSION}

\section{Selection among families}

The climate conditions in the SG and FCG generations were not favorable to the potato crop because high temperatures during the tuber development period were observed both in the field and in the greenhouse. In the FCG, the frequency of temperatures greater than $20{ }^{\circ} \mathrm{C}$ registered in the field was around $44 \%$, and double that in the greenhouse. The opposite occurred for the winter crop season with the SCG, in which the temperatures were adequate for the potato crop, with a frequency of $70.2 \%$ for temperatures below $20^{\circ} \mathrm{C}$.

The high temperatures observed in field conditions during the FCG contributed to reducing the tuber specific gravity, which decreased from 1.0761 in the winter crop season (SCG) to 1.0626 in the rainy crop season. That means that in the winter, the tubers had an average of around $20.8 \%$ dry matter, whereas in the rainy season, they had $17.8 \%$. This low dry matter content of the tubers disqualifies them for use in the form of French fries and becomes a problem for the processing industry in Brazil, which has difficulties in production of quality raw material in the rainy season. Consequently, Brazil has imported more than $70 \%$ of prefried frozen potatoes from Argentina and Europe (Ramos et al. 2013).

In the FCG in the field, the tuber yield of the families was greater than that observed in the SCG. These results differ from those found by Menezes et al. (1999), who observed reduction in the production of potato genotypes evaluated under high temperatures that occur in the rainy crop season in the south of Minas Gerais. The results presented here show that temperature was not the main difference between the winter crop season and the rainy crop season, since the trails were conducted in different areas. It should be noted that in the SCG, the environmental factors (low temperatures and high moisture) were favorable to late blight caused by Phytophthora infestans, leading to the loss of some plants and hindering tuber bulking and, consequently, lower tuber yield.

Another important aspect in selection experiments is the precision with which the treatments are evaluated. From accuracy estimates, it may be seen that precision was from moderate to very high for all traits (data not shown) (Resende and Duarte 2007), i.e., there is good reliability of estimation of genotypic values of families under testing based on experimental information.

The efficiency of selection in the first clonal generations may be evaluated by the correlation coefficients for a determined trait among the generations. Thus, high correlations should be expected between two generations if the behavior of the families were similar. In Table 1, it may be observed that the correlations for tuber yield were null or moderate, which means that selection of the most productive families in the SG did not result in more productive families in the FCG and SCG generations. Although there was significance for the correlation coefficient between the SG and the FCG in the greenhouse, this was of moderate magnitude. This may have occurred through the influence of seed-tuber size on clone performance in the succeeding generation, whereas SG was derived from true seeds, the other generations evaluated were obtained through vegetative propagation. The seed tuber used for vegetative propagation has more reserves stored and contributes to more vigorous development of the plant, in contrast with the true seed, which practically does not have reserves and germinates a small seedling which is much less vigorous.

The correlations for tuber yield were lower than those

Table 1. Pearson correlations between generations for tuber production, tuber specific gravity (TSG), shape, periderm texture, and eye depth based on evaluation of potato families and clones

\begin{tabular}{|c|c|c|c|c|c|c|}
\hline Traits & SG vs $\mathrm{FCG}_{\mathrm{GH}}$ & SG vs FCG FIELD & SG vs $\mathrm{SCG}_{\mathrm{FUD}}$ & $\mathrm{FCG}_{\mathrm{GH}}$ vs $\mathrm{FCG}_{\mathrm{FHELD}}$ & $\mathrm{FCG}_{\mathrm{GH}}$ vs $\mathrm{SCG}_{\mathrm{FIELD}}$ & $\mathrm{FCG}_{\mathrm{FIELD}}$ vs $\mathrm{SCG}_{\mathrm{FIELD}}$ \\
\hline Yield & $0.41^{* *}$ & 0.24 & 0.23 & $0.38^{*}$ & 0.15 & $0.43^{*}$ \\
\hline TSG & $0.51^{* *}$ & 0.28 & 0.22 & 0.18 & 0.12 & 0.17 \\
\hline Shape & - & $0.63^{* *}$ & $0.60^{* *}$ & - & - & $0.74^{* *}$ \\
\hline Periderm texture & $0.48^{* * *}$ & $0.38^{*}$ & 0.33 & 0.24 & $0.43^{*}$ & $0.49^{* *}$ \\
\hline Eye & 0.22 & $0.38^{* *}$ & $0.43^{*}$ & 0.18 & 0.33 & 0.33 \\
\hline
\end{tabular}

$*$,**: significant at $5 \%$ and $1 \%$, respectively 
observed by Kumar and Gopal (2006), who worked with 33 potato families of the SG up to the third clonal generation. Probably the lower correlations observed in the present study are due to the contrasting conditions of temperatures and planting, indicating greater difficulty in practicing early selection for yield under heat conditions. In addition, the authors evaluated the SG in the field, instead of in pots as in the present study, making the conditions more comparable and contributing to the greater correlation coefficient. Therefore, it seems that SG evaluation in the field could effectively contribute to family selection, although it is more laborious, because it requires transplanting of seedlings to the field.

The estimates of the coefficients of correlation between the generations for the other traits evaluated in families were also low. An exception is for tuber shape, which showed higher and more significant values (Table 1), ranging from 0.60 between the SG and SCG to 0.74 between the FCG and SCG. This would indicate success from family selection for tuber shape in early generations (SG and FCG), which is backed by other studies (Gopal and Minocha 1997, Amaro et al. 2003). For example, Amaro et al. (2003) found correlations for tuber shape, evaluated through the length/ diameter ratio, of 0.51 between individual clones and of 0.77 between mean values of families in the seedling generation and first clonal generation.

The mean yield values of the families in the SCG grown under mild temperatures were plotted on the $\mathrm{x}$ axis, and the mean values under heat stress conditions in the FCG in the field or in the greenhouse, on the $y$ axis. The case of a family having been selected in the FCG and discarded in the SCG indicates that the family in question is heat tolerant, but not responsive to mild temperatures. The opposite could also occur, i.e., the family having been discarded in the FCG and selected in the SCG. In this case, the family would not be heat tolerant, but it would have good performance under mild temperature conditions.

It was possible to see a discrepancy in the classification of the families evaluated in the FCG in the field (Figure 1) and in the greenhouse (figure not shown) in the four quadrants of the graphs. That occurred because there was no correlation for yield between the $\mathrm{FCG}_{\mathrm{GH}}$ and SCG (Table 1) because the environmental conditions were different among these environments. However, families 4, 10, and 11 were in quadrant I, considered as the most stable. This greater stability of the families hows that their behaviors are more predictable and that they undergo fewer negative impacts from high temperatures, ensuring greater yields for them in various environments.

In Figure 1, it can be seen that the families that showed the greatest mean values for yield were 4, 10, 11, 15, 16, 19, and 32. Besides them, the heat tolerant clones, CBM 09-10 and CBM 16-16, showed high mean values. In contrast, the control cultivars, Caesar and Asterix, were located in quadrant III, showing the lack of adaptation to heat stress. Therefore, utilization of these families probably makes it possible to obtain heat tolerant clones, yet clones that would be productive if grown under favorable temperature conditions.

Based on the mean yields and tuber specific gravity, families were ranked for each generation. Thus, selecting $60 \%$ of the most productive families in the FCG in the field and $40 \%$ of the best families in the SCG, it was seen that $67 \%$ of the families coincided. Upon using the same selection intensity in the FCG $(60 \%)$ and $50 \%$ in the SCG, it was observed that $73 \%$ of the families coincided. Therefore, early discard in the FCG would be eliminating families that in fact would not show good performance in the more advanced generation (SCG). Benavente and Pinto (2012) who worked with selection for tuber yield among

A
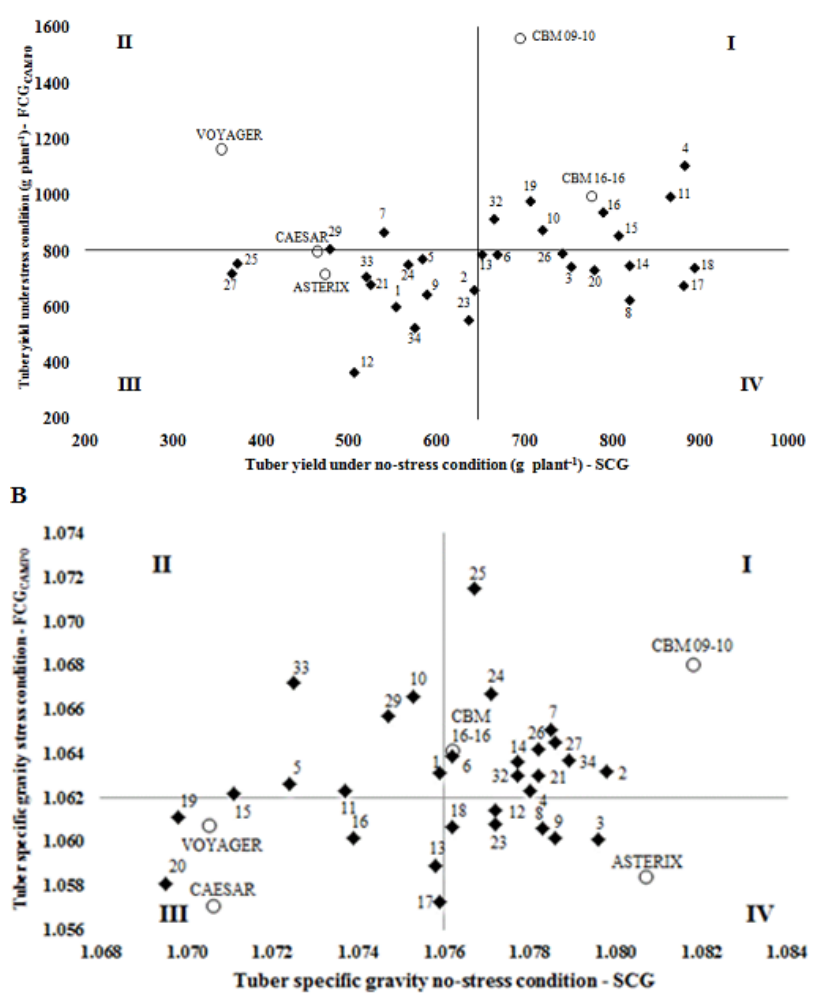

Figure 1. Distribution of mean values of families for tuber yield (A) and tuber specific gravity (B) under mild temperatures in the second clonal generation - SCG ( $x$ axis) and under heat stress in the first clonal generation in the field $-\mathrm{FCG}_{\mathrm{FIELD}}$ (y axis). 
potato families under high temperature conditions, found that selection intensities from $50 \%$ to $60 \%$ led to the best responses in clone selection.

By the same reasoning, however with the FCG evaluated in a greenhouse, it can be seen that the coincidence of the best families with the SCG was always less than the FCG evaluated in the field. In a certain way, this was expected, given the difference of the conditions of the FCG in the greenhouse and the SCG in the field. Thus, it would not be advisable to undertake family selection for tuber yield in the FCG in the greenhouse using small diameter pots. This result is corroborated by the study of Verissimo et al. (2012) who studied the influence of small pot size on the expression of tuber traits in potato families in the SG. These authors observed that pots with $1 \mathrm{~L}$ capacity allowed greater expression of production traits in comparison with pots of $0.25 \mathrm{~L}$ capacity and, consequently, they allowed better estimates of genetic variability among the families.

In the case of family selection for tuber specific gravity in the FCG, efficiency of family selection was observed both in the field and in the greenhouse. For example, with selection intensities from $50 \%$ to $60 \%$ among families in the FCG in the field or greenhouse, and $40 \%$ to $50 \%$ in the SCG, the coincidence of families selected was $67 \%$ both in evaluation in the field and in the greenhouse. This efficiency of family selection for tuber specific gravity in a greenhouse may have occurred as a result of the small family $\mathrm{x}$ environment interaction for this trait.

Thus, selection intensities among families from $40 \%$ to $60 \%$ lead to the best family coincidences and allow elimination of a reasonable proportion of clones that would not be evaluated in subsequent generations.

\section{Clonal selection within families}

The temperatures observed in the winter crop season (C2) were more favorable to potato growing; in approximately $60 \%$ of the crop development period, they were below 20 ${ }^{\circ} \mathrm{C}$. The opposite occurred in the rainy crop season (C3), in which the frequency of temperatures greater than $20^{\circ} \mathrm{C}$ was $72 \%$, and even arrived at values greater than $25^{\circ} \mathrm{C}$ in $23 \%$ of this period.

The mean values of the traits evaluated under thermal stress (rainy crop season) were low, with a $36 \%$ decline in tuber yield and $2.12 \%$ decline in tuber specific gravity, when compared to the mean values of the favorable environment (winter crop season). The mean value of the percentage of physiological disorders (second growth and cracking) was also high in the rainy crop season, showing the strong effect of heat stress on the genotypes evaluated.

Among the controls evaluated in the clonal generations (C2 and C3), only the clone CBM 09-10 is found in quadrant I for tuber yield. The clone CBM 16-16 showed good performance under mild temperatures; however, it did not do well under heat conditions, as was observed in previous studies (Menezes et al. 2001) and even observed in the family experiment in this study. The control cultivars, for their part, did not tolerate high temperatures and did not respond to mild temperatures in a satisfactory manner (Figure 2).

For tuber specific gravity, the control clones had a greater mean value in the unfavorable environment and were responsive to environmental improvement. The opposite occurred to the cultivars Voyager and Caesar, which had low mean values both under high temperature and mild temperature conditions. The Asterix cultivar was greater than the mean value under high temperatures; however, it did not respond to improvement in the environment and was thus situated in quadrant II (Figure 2).

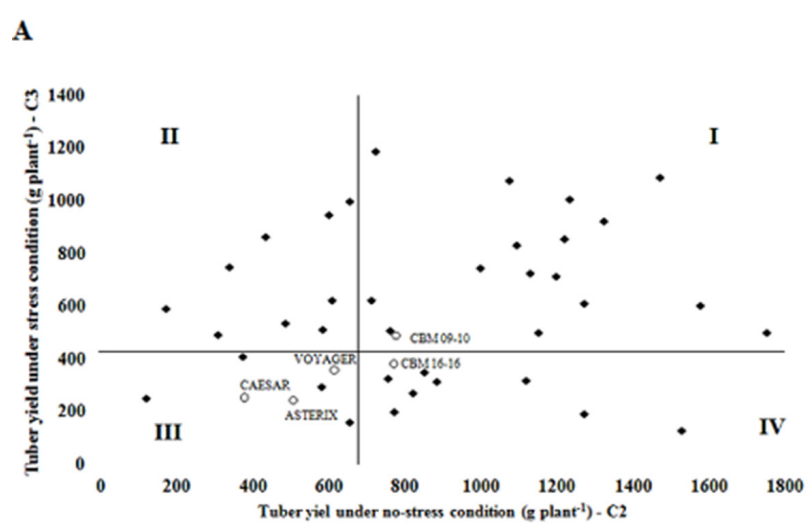

B

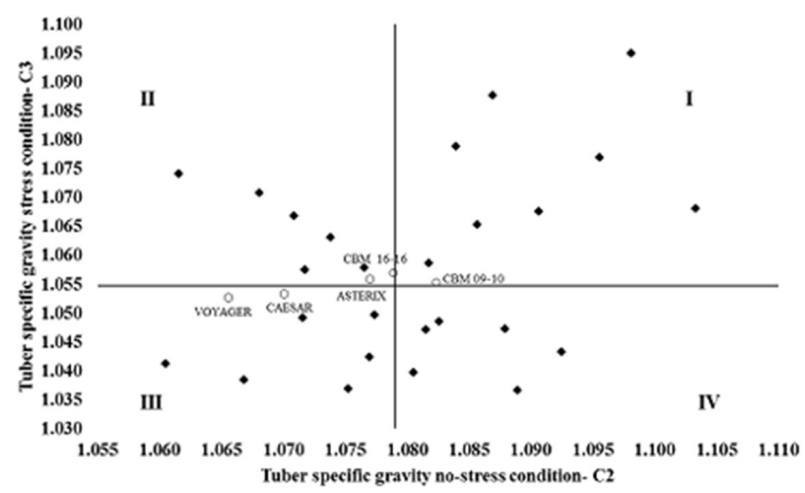

Figure 2. Distribution of the mean values of clones for tuber yield (A) and tuber specific gravity (B) under mild temperatures in the second clonal generation - $\mathrm{C} 2(\mathrm{x}$ axis) and under heat stress in the third clonal generation - $\mathrm{C} 3$ (y axis). 
To verify if family selection in the FCG and/or SCG was efficient, we sought to identify the quadrant where the clone and its family of origin would stand. The percentage was estimated considering that the clone populations of the quadrants involved have the same size. For tuber yield, it was observed that $63.4 \%$ of the clones tolerant to heat stress and responsive to environmental improvement (Quadrant I - QI) came from tolerant families (QI + QII), i.e., of the 84 clones of quadrant I, 59 came from families of quadrants I and II. For the non-tolerant and non-responsive clones (QIII), 58.3\% came from non-tolerant families (QIII + QIV) evaluated in the field. In other words, family selection in the FCG in the field under high temperature conditions was efficient in identifying the desired clones. In addition, it was observed that discarding the worst families would mainly be eliminating the worst clones.

However, when the FCG was grown in a greenhouse, it was observed that only $41.1 \%$ of the clones of quadrant I belonged to tolerant families, and $37.6 \%$ of the clones of quadrant III came from non-tolerant families. Once more, these results reinforce that evaluation of the FCG in a greenhouse using small diameter pots was not efficient for selecting the most productive families. The use of larger pots might permit a more discriminating selection of the families, as advocated by Veríssimo et al. (2012), even under high temperatures.

When family selection is made based on SCG under mild temperature conditions, it was observed that $69.8 \%$ of the tolerant and responsive clones (QI) came from responsive families (QI + QIV). Thus, family selection in the SCG for responsiveness to mild temperatures was also efficient. Using information from heat-stress-tolerant families in the FCG evaluated in the field and responsive to environmental improvement in the SCG, it was observed that around 70\% of the tolerant and responsive clones (QI) originated from these families.

For tuber specific gravity, it was observed that around $60 \%$ of the clones tolerant to thermal stress and responsive to environmental improvement are from tolerant families evaluated in the field and $63 \%$ of the non-tolerant and nonresponsive clones are from non-tolerant families. When selection is made based on the mean value of the FCG in the field and the SCG, it was observed that $56 \%$ of the clones tolerant to high temperatures and responsive to mild temperatures come from tolerant and responsive families. It was also seen that evaluation of the FCG in a greenhouse did not contribute to improving the efficiency of family selection for tuber specific gravity.

Several clones exhibited better behavior for the set of

Table 2. Mean value of the clones selected for total yield $\left(\mathrm{g} \mathrm{plant}^{-1}\right)$, tuber specific gravity, tuber shape, periderm texture, eye depth, general tuber appearance, percentage of second growth tubers, and percentage of cracked tubers

\begin{tabular}{|c|c|c|c|c|c|c|c|c|c|c|c|c|c|c|c|c|}
\hline \multirow[t]{2}{*}{ Genotype } & \multicolumn{2}{|c|}{$\begin{array}{c}\text { Yield } \\
\left(\text { g plant }^{-1}\right)\end{array}$} & \multicolumn{2}{|c|}{$\begin{array}{c}\text { Tuber specific } \\
\text { gravity }\end{array}$} & \multicolumn{2}{|c|}{ Shape } & \multicolumn{2}{|c|}{$\begin{array}{l}\text { Periderm } \\
\text { texture }\end{array}$} & \multicolumn{2}{|c|}{ Eye } & \multicolumn{2}{|c|}{$\begin{array}{l}\text { General tuber } \\
\text { appearance }\end{array}$} & \multicolumn{2}{|c|}{$\begin{array}{l}\text { \% tubers } \\
\text { with second } \\
\text { growth }\end{array}$} & \multicolumn{2}{|c|}{$\begin{array}{l}\% \text { cracked } \\
\text { tubers }\end{array}$} \\
\hline & winter & rainy & winter & rainy & inter & rainy & winter & rainy & winter & rainy & winter & rainy & winter & rainy & winter & rainy \\
\hline SR3 11-09 & 902.14 & 925.57 & 1.0805 & 1.0551 & 4.91 & & & & 3.83 & & & & 0.00 & 33 & 0 & 0.00 \\
\hline SR3 11-23 & 1234.23 & 1012.73 & 1.0746 & 1.0570 & 5.00 & 3.63 & 40 & 2.46 & 2.90 & 3.69 & 2.91 & 2.55 & 0.00 & 0.00 & .00 & 0.00 \\
\hline SR3 11-29 & 874.66 & 723.40 & 1.0789 & 1.0652 & 2.51 & 2.74 & 4.07 & 3.28 & 4.56 & 2.94 & 3.27 & 3.64 & 0.00 & 0.00 & 0.00 & 0.00 \\
\hline SR3 16-29 & & & & & & & & & & & & & & & & 0.00 \\
\hline SR3 16-33 & 1199.22 & 720.57 & 1.0750 & 1.07 & 4.51 & 3. & & & 3.90 & & & & 0.00 & 0.00 & 0 & 0.00 \\
\hline SR3 19-24 & 891.33 & 766.60 & 1.0822 & 1.0627 & 4.77 & 3.9 & 91 & 2.59 & 3.48 & 3.58 & 3 & 2 & 0.00 & 0.00 & 0.00 & 0.00 \\
\hline SR3 19-28 & 868.40 & 0.57 & 1.0784 & 1.0638 & 3.97 & 3.4 & 1.80 & 2.67 & 3.16 & 3.9 & 2.41 & 2.40 & 0.00 & 0.00 & 0.00 & 0.00 \\
\hline SR3 19-34 & 830.48 & 895.25 & 1.0827 & 1.0631 & 1.04 & 2.18 & 3.67 & 3.37 & 3.70 & 2.32 & 3.47 & 2.57 & 0.00 & 0.00 & 0.00 & 0.00 \\
\hline CBM 09-10 & 781.00 & 489.42 & 1.0824 & 1.0553 & 3.64 & 2.96 & 3.39 & 2.85 & 2.87 & 2.81 & 2.68 & 2.11 & 0.00 & 0.00 & 22.22 & 21.00 \\
\hline CBM 16-16 & 775.68 & 382.27 & 1.0789 & 1.0570 & 2.56 & 2.74 & 2.43 & 2.52 & 3.69 & 2.95 & 2.96 & 2.55 & 0.00 & 3.70 & 0.00 & 6.90 \\
\hline ASTERIX & 509.82 & 244.01 & 1.0770 & 1.0559 & 4.96 & 4.40 & 3.16 & 3.20 & 4.12 & 3.44 & 3.13 & 2.49 & 25.00 & 10.70 & 25.00 & 0.00 \\
\hline CAESAR & 382.15 & 253.40 & 1.0701 & 1.0533 & 4.60 & 3.78 & 3.66 & 2.94 & 4.24 & 3.41 & 3.59 & 2.73 & 0.00 & 4.60 & 41.67 & 8.80 \\
\hline VOYAGER & 618.32 & 358.76 & 1.0655 & 1.0527 & 4.78 & 3.27 & 3.69 & 3.16 & 4.23 & 3.29 & 2.99 & 2.94 & 0.00 & 6.00 & 29.41 & 4.20 \\
\hline Overall mean & 637.50 & 407.40 & 1.0775 & 1.0546 & 3.19 & 2.89 & 2.79 & 2.72 & 3.50 & 2.97 & 2.71 & 2.34 & 0.76 & 3.00 & 4.75 & 16.58 \\
\hline
\end{tabular}


traits evaluated (Table 2) and, therefore, they may potentially be used as parents and may proceed in a recurrent selection program with a view toward heat tolerance. The clones SR3 11-09, SR3 16-18 (elongated), SR3 19-34 (round), and SR3 25-14 (oval) stood out, exhibiting the greatest mean values in the environment with heat stress. In addition, they had other interesting traits, such as intermediate texture of the periderm, relatively shallow eyes, and absence of physiological disorders.

It is important to compare the tuber specific gravity of the clones with those of the controls since the clones exhibited a high tuber specific gravity, especially in relation to the Asterix cultivar, used as the standard cultivar for prefried frozen processing in Brazil. The clone SR3 16-33 of elongated shape is noteworthy because it had greater tuber specific gravity in the heat and high yield, and it could be recommended for the pre-fried frozen industry. Another factor that draws attention is that most of the clones had production per plant greater than the mean values of the controls, even of those tolerant to the heat (Table 2).

Domestic use (table) requires clones with multiple uses and good tuber appearance. Among them, the clones SR3 11-29 and SR3 32-22, both of oval shape, and the clone SR3 19-24 of elongated shape, were quite productive, had good tuber appearance, and had tuber specific gravity greater than the control cultivar Asterix.

\section{CONCLUSIONS}

Family selection in the first clonal generation evaluated in the field was efficient in identifying the clones most tolerant to heat and responsive to milder temperatures for yield and tuber specific gravity.

The clones that stood out are derived from the best families selected, i.e., around $70 \%$ of the clones tolerant to heat stress and responsive to environmental improvement belong to families tolerant to heat stress and responsive to mild temperatures.

\section{ACKNOWLEDGMENTS}

The authors thank the National Council of Scientific and Technological Development (CNPq) for financial support.

\section{Eficiência de seleção em gerações precoces de famílias de batata visando a tolerância ao calor}

Resumo - O objetivo deste trabalho foi avaliar a eficiência da seleção de famílias de batata nas gerações precoces para tolerância a calor. Foram avaliadas 30 famílias na geração seedling (SG), primeira geração clonal (FCG) em campo e casa de vegetação sob condições de temperaturas elevadas e segunda geração clonal (SCG) sob temperaturas amenas e obtidas as médias das famílias em cada geração. Foram selecionadas 16 famílias mais produtivas na FCG e os clones dessas famílias foram avaliados em experimentos nas safras de inverno e "das águas". Os resultados mostraram que a seleção de famílias para formato de tubérculos pode ser aplicada desde a SG. Também observou-se que a seleção de famílias na FCG e SCG para produtividade e peso específico de tubérculos contribuiu para a identificação de clones tolerantes ao calor e responsivos a melhoria ambiental.

Palavras-chave: Seleção precoce, clones, Solanum tuberosum, estresse térmico.

\section{REFERENCES}

Amaro GB, Pinto CABP, Lambert ES and Neto CLM (2003) Seleção precoce de clones de batata para caracteres dos tubérculos. Ciência e Agrotecnologia 27: 585-589.

Benavente CAT and Pinto CABP (2012) Selection intensities of families and clones in potato breeding. Ciência e Agrotecnologia 36: 60-68.

Benites FRG and Pinto CABP (2011) Genetic gains for heat tolerance in potato in three cycles of recurrent selection. Crop breeding and applied biotechnology 11: 133-140.

Bradshaw JE, Dale MFB, Swan GEL, Todd D and Wilson RN (1998) Early-generation selection between and within pair crosses in potato (Solanum tuberosum subsp. tuberosum) breeding programme. Theoretical and Applied Genetics 97: 1331-1339.

Brown J, Calegari PDS, Mackay GR and Swan GEL (1987) The efficiency of visual selection in early generations of a potato breeding programme. Annals of Applied Biology 110: 357-363.

Dias CAC (1993) Cultura da batata. Secretaria de Agricultura e Abastecimento, Campinas, 33p. (Documento Técnico da CATI, 65).

Diniz MCDR, Pinto CABP and Lambert ES (2006) Sample size for family evaluation in potato breeding programs. Ciência e Agrotecnologia 30: $277-282$.

Fageria NK and Kluthcouski J (1980) Metodologia para avaliação das cultivares de arroz

e feijão para condições adversas de solo. Embrapa, CNPAF, 22p. (Circular Técnica, 8).

Ginzberg I, Barel G, Ophir R, Tzin E, Tanami Z, Muddarangappa T, Jong W and Fogelman E (2009) Transcriptomic profiling of heat-stress response in potato periderm. Journal of Experimental Botany 60: 4411-4421. 
Gopal J and Minocha JL (1997) Effectiveness of selection at microtuber crop level in potato. Plant Breeding 116: 293-295.

Gopal J (1997) Progeny selection for agronomic characters in early generations of potato breeding programme. Theoretical and Applied Genetics 95: 307-311.

Hancock RD, Morris WL, Ducreux LJM, Morris JA, Usman M, Verrall SR, Fuller J, Simpson CG, Zhang R, Hedley PE and Taylor MA (2013) Physiological, biochemical and molecular responses of the potato (Solanum tuberosum L.) plant to moderately elevated temperature. Plant, Cell and Environment 37: 439-450.

Haverkort AJ and Verhagen A (2008) Climate change and its repercussions for the potato supply chain. Potato Research 51: 223-237.

Hijmans RJ (2003) The effect of climate change on global potato production. American Journal Potato Research 80: 271-279.

IBGE - Instituto Brasileiro de Geografia e Estatística (2013) Available at $<$ http://www.ibge.gov.br/home/estatistica/indicadores/agropecuaria/ 1spa/lspa_201405_2.shtm >. Accessed on 10 Aug, 2014.

Kumar R and Gopal J (2006) Repeatability of progeny mean, combining ability, heterosis and hetebeltiosis in generations of a potato breeding programme. Potato Research 49: 131-141.

Levy D and Veilleux RE (2007) Adaptation of Potato to High Temperatures and Salinity - A Review. American Journal of Potato Research 84: 487-506.

Menezes CB, Pinto CABP, Nurmberg PL and Lambert ES (1999) Avaliação de genótipos de batata (Solanum tuberosum L. nas safras "das águas" e de inverno no sul de Minas Gerais. Ciência e Agrotecnologia 23: 776-783.

Menezes CB, Pinto CABP and Lambert ES (2001) Combining ability of potato genotypes for cool and warm seasons in Brazil. Crop breeding and applied biotechnology 1: 145-157.

Ramos RM, Silva AR and Dumbra JGR (2013) O aquecido mercado dos vegetais congelados. Hortifruti Brasil 122: 8-21.

Resende MDV (2007) Software SELEGEN - REML/BLUP: Sistema estatístico e seleção computadorizada via modelos lineares mistos. Embrapa, Colombo, 359p.

Resende MDV and Duarte JB (2007) Precisão e controle de qualidade em experimentos de avaliação de cultivares. Pesquisa Agropecuária Tropical 37: 182-194.

SAS Institute (2000) SAS/STAT user's guide. Version 8, SAS Institute, Cary.

Simmonds NW (1996) Family selection in plant breeding. Euphytica 90: 201-208.

Simon GA, Pinto CABP and Benites FRG (2009) Seleção de famílias clonais de batata em diferentes ambientes. Ciência e Agrotecnologia 33: 164-169.

Verissimo MAA, Pereira AS, Silva DAS, Terres LR, Ney VG and Silva GO (2012) Expressão de caracteres de tubérculos em função do tamanho de recipiente usado no cultivo de batata na geração de plântulas. Revista Ceres 59: 787-793. 